\title{
ГІСТОАРХІТЕКТОНІКА ЛІМФОЇДНИХ УТВОРЕНЬ СЛИЗОВОЇ ОБОЛОНКИ ТОНКОГО КИШЕЧНИКА МУСКУСНИХ КАЧОК
}

\author{
Логвінова Віта Володимирівна \\ кандидат ветеринарних наук, старший викладач \\ Дніпровський державний аграрно-економічний університет, (Дніпро, Україна) \\ ORCID: 0000-0002-2084-6850 \\ lohvinova.v.v@dsau.dp.ua \\ Оліяр Алла Вячеславівна \\ кандидат ветеринарних наук, доцент \\ Дніпровський державний аграрно-економічний університет, (Дніпро, Україна) \\ ORCID: 0000-0002-8918-2693 \\ oliiar.a.v@dsau.dp.ua
}

Особливості морфогенезу лімфоїдних структур кишечника свійської птиці, зокрема в період від народження до настання фрізіологічної зрілості, коли відбувається інтенсивне фрормування імунної системи, необхідно враховувати в інтенсивному птахівництві, що визначає широке використання біологічних препаратів з активною антигенною дією. Від здорових не вакцинованих качок відбирали дванадцятипалу, порожню та клубову кишки, досліджували за загальними методиками: макро-мікроанатомію і топограффію лімфоїдних структур слизової оболонки тонкої кишки, проводили за методикою Hellman, парафрінові гістологічні зрізи забарвлювали гематоксиліном Ерліха та еозином, азур II-еозином та імпрегнували сріблом за Футом. Вік піддослідних качок: 1, 5, 10, 15, 20, 25, 30, 60, 90, 120, 150, 180, 210 та 240 діб. Встановлено, що морфо-функціональна диференціація та спеціалізація лімфоїдних утворень тонкої кишки має вікові та регіональні особливості, відбувається в певній послідовності. В слизовій оболонці дванадиятипалої та клубової кишок качок з 25-добового віку паралельно з дифузною лімфоїдною тканиною відбувається формування ретикулярної строми лімфатичних вузликів. У зрілому (реактивному) вузлику, зародковому чентрі та периферійній частині чітко виділяються мантія, що складається, переважно, з дрібних лімфоцитів. Характерно, що кількість і розмір вузликів збільшується з віком. Ретикулярна сітка лімфатичних вузликів при цьому розріджується, до її часткового витончення, а в подальшому й фрагментації.

Ключові слова: дифузна лімфоїдна тканина, лімфатичні вузлики, агреговані лімфратичні вузлики, лімфоїдні клітини, дванадиятипала, порожня та клубова кишки, мускусна качка.

DOI: https://doi.org/10.32845/bsnau.vet.2021.1.5

Вступ. У сучасних умовах актуальним $є$ дослідження особливостей будови і функції імунної системи продуктивної птиці, зокрема, лімфоїдних структур, асоційованих із слизовою оболонкою трубкоподібних органів, морфофункціональний статус яких визначає стан природної резистентності та реактивності органів апарату травлення (Birka, 2019; Kotsiumbas et al., 2019). Ця проблема набуває особливого значення в умовах промислового птахівництва, що спричинено негативним впливом антропогенних факторів на показники життєздатності птиці (Makhotina et al., 2020).

Через травну систему в організм птиці проходить величезний потік антигенного матеріалу, стимуляція яким відповідних утворень слизової оболонки кишечнику сприяє розвитку, вдосконаленню і диференціації його лімфоїдних утворень, що забезпечують імунний захист як на рівні органа, так і в масштабах всього організму. Для забезпечення відносної сталості внутрішнього середовища травний канал птиці володіє потужними механізмами захисту (GALT - gut associated lymphoid tissue), основними з яких є клітинні (інтраепітеліальні лімфоцити, лімфоцити lamina propria, плазматичні клітини, макрофагоцити та ін.) і тканинні структурні елементи (поодинокі та агреговані лімфатичні вузлики (АЛВ)) (Mazurkevych \& Khomych, 2017). Серед лімфоїдних утворень кишечнику значне місце за масою лімфоїдної тканини належить АЛВ, які являють собою найбільш високоорганізовані компоненти імунної системи цього органа (Birka, 2019).

Особливості морфогенезу лімфоїдних структур кишечника свійської птиці, особливо в період від народження і до настання фізіологічної зрілості, коли відбувається інтенсивне становлення імунної системи, необхідно пильно враховувати

в умовах інтенсивного птахівництва, яке визначає широке використання біологічних препаратів, що мають активну антигенну дію. Проте, закономірності морфогенезу периферійних лімфоїдних органів найбільш детально досліджені в людини, лабораторних тварин та деяких видів продуктивних ссавців. Особливості будови лімфоїдних структур, асоційованих із слизовими оболонками трубкоподібних органів мускусної качки до сьогодні залишаються не з'ясованими.

Незважаючи на те, що в останні роки в багатьох країнах Європи мускусні качки та їх гібриди широко використовують для промислового розведення, особливості морфологічного статусу їх лімфоїдних утворень, асоційованих із слизовою оболонкою трубкоподібних органів, залишаються майже не з'ясованими. Відсутні також відомості щодо закономірностей архітектоніки ретикулярного остова та динаміки клітинного складу на різних стадіях формування імунних структур тонкої кишки мускусних качок.

Аналіз останніх досліджень і публікацій. Місцева імунна система за твердженням (Makhotina D.S.,2020) травного каналу забезпечує дві функції: 1) розпізнавання та індукцію толерантності до кормових антигенів; 2) блокуючий ефект по відношенню до патогенних мікроорганізмів. Мигдалини здійснюють місцевий захист шляхом виділення в порожнину глотки імуноглобулінів, інтерферону, лізоциму, лімфоцитів, макрофагів і простагландинів. Вони сприяють формуванню імунної пам'яті шляхом утворення клону лімфоцитів, які готують імунну систему до повторної зустрічі з антигенами. Групові лімфатичні вузлики, або ПБ, будучи імунокомпитентними елементами тонкої кишки приймають участь у розпізнанні кормових антигенів хімусу і формуванні місцевої 
імунної відповіді. Імунокомпетентна (лімфоїдна) тканина ШКТ представлена організованими структурами (ПБ, апендикс, мигдалини, лімфатичні вузли) і окремими клітинними елементами (інтраепітеліальні лімфоцити, плазматичні клітини, макрофаги, тучні клітини, гранулоцити). Популяція клітин лімфоїдної тканини різнорідна і складається з безлічі груп, підгруп і клонів клітин з різними функціональними властивостями і специфічністю рецепторів до антигенів.

В імунній системі розрізняють центральні і периферичні органи. До центральних органів птиці відносяться: ембріональний жовтковий мішок, кістковий мозок, тимус і клоакальна сумка, а до периферичних - селезінка, залоза Гардера, слізна залоза, дивертикул Меккеля, мигдалини сліпих кишок, ДЛТ трубкоподібних органів. Така розкиданість ЛТ пояснюється тим, що у курей, через відсутність лімфатичних вузлів, речовини, що володіють властивістю антигенів, фіксуються поблизу місць проникнення - в органах травлення і дихання з подальшим розвитком у відповідь реакції у вигляді активної проліферації лімфоїдних клітин. Якщо ж антиген проникає в кров, то він елімінується і фіксується головним чином в селезінці. Загальна кількість ЛТ у птиць досягає 1\% від маси тіла. Експериментально встановлено, що у птиці диференціювання і дозрівання лімфоцитів контролюються двома органами - тимусом і клоакальною сумкою. В тимусі дозрівають і диференціюються Т-лімфоцити. У клоакальній сумці - В-лімфоцити. Таку особливість імунної системи птиці підтвердили (Takeuchi, T., Kitagawa, Н., Imagawa, T., \& Uehara, M., 1998) при використанні антисироваток проти Т-лімфоцитів i В-лімфоцитів.

Багато робіт присвячено вивченню будову ЛТ тонкої кишки курчат, що по своїм гістологічним характеристикам відповідає пейеровим бляшкам ссавців (Kajiwara, E., Shigeta, A., Horiuchi, H., Matsuda, H., \& Furusawa, S 2003). Як стверджує у своїх дослідженнях Сапін М.Р. ЛТ складається з багаточисельних лімфатичних вузликів, розміщених у власній пластинці слизової оболонки. Поверхня ЛТ направлена в просвіт кишки, представлена ворсинками. Клітини епітелія, що лежать поверх ворсинок, морфологічно ідентичні клітинам ссавців. Як зазначають (Makhotina D.S., Kushch M.M., Miroshnikova O.S. 2020) ПБ - це добре організовані імунокомпетентні структури шлунково-кишкового тракту (ШКТ) птиці. ПБ тонких кишок необхідні для дозрівання $T$ - і $B$-лімфоцитів і забезпечення організму секреторним IgA, вони формують імунну відповідь на місцевому рівні й детермінують системну імунну відповідь (Takeuchi, T., Kitagawa, H., Imagawa, T., \& Uehara, M., 1998).

В даний час велика увага приділяється лімфоїдним утворенням кишечника. До високоорганізованих утворень кишечника відносять пейерові бляшки, що були вперше описані у людини в 1677 році відомим швейцарським ученим Іоганом Пейером, який вважав, що вони є травними залозами кишечника. Але лише останнім часом було доведено їх участь в реакціях імунітету. У птиці лімфоїдні бляшки зустрічаються в області переходу стравоходу в залозистий відділ шлунку (стравохідна «мигдалина»), в клубовій кишці (пейерові бляшки) і на внутрішній стінці сліпих кишок (сліпокишкові «мигдалини») (Makhotina D.S., Kushch M.M., Miroshnikova O.S. 2020). Серед них найбільш виражені парні сліпокишкові лімфоїдні бляшки, які розташовуються в проксимальних ділянках сліпих кишок. Вони виступають в просвіт кишечника у вигляді округлих утворень, покритих ворсинками (Kalinovskaya, I.G., 2005). Площа, що зайнята сліпокишковими лімфоїдними бляшками, з віком збільшується з 9,0 мм2 в 10-ти денному віці до 40,0 мм2 в 30-ти денному віці.

ПБ беруть участь у формуванні імунної відповіді в лімфопоезі і рециркуляції лімфоцитів. Вони представлені скупченням ДЛТ і ЛВ3, які щільно прилягають одне до одного і розміщуються в слизовій оболонці і підслизовій основі кишки. Макроскопічно, зі сторони просвіту кишки ПБ випинаються над поверхнею слизової оболонки. На поверхні ПБ помітні ямки, в просвіті яких розміщуються купола групових ЛВ3 (Kalinovskaya, I.G., 2005). Наряду з червоподібним відростком, піднебінними і глотковими мигдалинами, ПБ відносять до високоорганізованих лімфоїдних утворень шлунково-кишкового тракту, що представляють невід'ємний і важливий елемент імунної системи організму. В найбільшій кількості ПБ розміщуються в тонкій кишці ссавців (Havrylin P.M., Nikitina M.O., 2017). В пренатальному періоді онтогенезу формування ПБ у людини характеризується загальними закономірностями: їх закладка починається у стінці клубової кишки.

Основна гістологічна особливість сліпокишкових бляшок - це лімфоїдні утворення, які разом із загальнокишковими залозами, розташовуються в товщі слизової оболонки (Makhotina D.S., Kushch M.M., Miroshnikova O.S., 2020). Лiмфоїдна тканина, представлена дифузними скупченнями і вузликами (фолікулами), з'являється у курчат в 15-ти денному віці і досягає максимального розвитку до статевого дозрівання. Надалі відбувається зменшення кількості лімфоїдної тканини і розростання сполучних елементів.

Знання закономірностей морфогенезу лімфоїдних структур кишечнику свійської птиці є необхідними для більш глибокого розуміння патогенезу хвороб органів травлення, а також створення ефективних методів імунокорекції, імуностимуляції та імунопрофрілактики в умовах ії інтенсивного вирощування. Аспекти морфогенезу периферійних лімфоїдних органів найбільш детально досліджені в людини, лабораторних тварин (Havrylin \& Nikitina, 2017) та деяких видів продуктивних ссавців (Samoiliuk et al., 2019; Tishkina \& Oliiar, 2013). Серед продуктивної птиці найбільш глибоко досліджені пейєрові бляшки курей (Jung et al., 2010; Kalinovskaya, 2005), лімфатичні вузли гусей та качок (Birka, 2019). Лімфатичні вузлики тонкої кишки - це клітинні скупчення округлої або овальної форми, які складаються з петель ретикулярної тканини, утвореної ретикулярними клітинами, волокнами і клітинами лімфоїдного ряду (лімфоцитів різної величини і ступеня зрілості, плазмоцитів, макрофагів). У зрілому вузлику розрізняють центр розмноження (гермінативний центр) та периферію (мантію), утворену дрібними клітинами, переважно, малими лімфоцитами, що формують скупчення навколо центру розмноження, в якому клітини лежать більш розріджено, ніж на периферії. Окрім центральної і периферичної зон у зрілих лімфатичних вузликах слизової оболонки розрізняють субепітеліальну та навколовузликову зони (Mazurkevych, 2020), а також виділяється обідок з ретикулярних волокон, який утворює своєрідну капсулу і надає їм форму.

Мета. 3'ясувати особливості постнатального морфогенезу лімфоїдних утворень слизової оболонки тонкого кишечника мускусних качок.

Матеріали та методи дослідження. Дослідження проводили в лабораторії гістології, імуноцитохімії та патоморфології Науково-дослідного центру біобезпеки та екологічного контролю ресурсів АПК Дніпровського державного аграрно-економічного університету. Досліджували дванадцятипалу, порожню та клубову кишки клінічно здорових, не вакцинованих мускусних качок віком 1, 5, 10, 15, 20, 25, 30, 60, 90, 
120, 150, 180, 210 та 240 діб (по 5 голів у кожній групі), вирощених в умовах віварію.

Дослідження макро-мікроанатомії і топографрії лімфоїдних структур слизової оболонки кишечника проводили із застосуванням методики тотального фрарбування за Хелман. Відібрані органи фіксували у 10\%-му розчині формаліну з подальшим виготовленням тотальних парафінових (3-5 мкм) гістологічних зрізів, їх забарвленням гематоксиліном Ерліха та еозином, азур II - еозином та імпрегнацією сріблом за Футом за загальноприйнятими методиками (Horalskyi et al., 2019). Мікропрепарати досліджували під світловим мікроскопом Leica DM 1000, фрото виготовляли з використанням програми LAS V4.12.

На площі зрізу визначали наявність лімфоїдної тканини та різних стадіях її диференціації (скупчення лімфоїдної тканини, лімфатичні вузлики, лімфатичні вузлики з центрами розмноження), стадії розвитку лімфатичних вузликів (дифузна лімфоїдна тканина, предвузлик, лімфатичний вузлик, лімфатичний вузлик з центром розмноження), якісні показники лімфатичних вузликів, характер розміщення лімфоїдної тканини та лімфатичних вузликів у товщі слизової оболонки, а також її особливості.

Експериментальні дослідження проведені із дотриманням вимог статті 26 Закону України №5456-VI від 16.10.2012 р. «Про захист тварин від жорстокого поводження» та Директиви ЄС 86/609/ЄЄС від 24.11.1986 р., узгоджуються з основними принципами Європейської конвенції «Про захист хребетних тварин, які використовуються для дослідних та інших наукових цілей" (Страсбург, 18.03.1986р.), декларації "Про гуманне ставлення до тварин" (Гельсінкі, 2000 р.) і Першого Національного конгресу з біоетики "Загальні етичні принципи експериментів на тваринах" (Київ,
20.09.2001 р.).

Результати дослідження. Структура лімфоїдних утворень слизової оболонки тонкої кишки мускусних качок характеризується рядом закономірностей. Процес морфофункціональної диференціації і спеціалізації лімфоїдних утворень тонкої кишки в мускусних качок відбувається у певній послідовності: від стадії концентрації лімфоїдних клітин (5-, 10-, 15-добова птиця) до формування поодиноких, а в подальшому й агрегованих лімфатичних вузликів без центрів та з центрами розмноження (60-, 90-, 240-добова птиця).

Лімфоїдні структури слизової оболонки дванадцятипалої кишки в мускусних качок представлені виключно дифузною лімфоїдною тканиною (ДЛТ) та поодинокими лімфатичними вузликами (ЛВ3), що з'являються, починаючи з 20-25добового віку, кількість яких поступово збільшується до настання статевої зрілості.

Вторинні ЛВЗ, як основні морфологічні маркери імунокомпетентності, в слизовій оболонці дванадцятипалої кишки качок виявляються, переважно, в статевозрілих (210-240-добових) особин. Характерні для даного органа ссавців агреговані ЛВ3 у качок у дванадцятипалій кишці не виявляються.

На відміну від дванадцятипалої кишки основними лімфоїдними структурами слизової оболонки порожньої і клубової кишок мускусних качок $€$ агрегати лімфатичних вузликів або пейєрові бляшки (ПБ). В порожній кишці мускусних качок ПБ вперше виявляються в 25-добовому віці і містять всі характерні для даних структур паренхіматозні та стромальні компоненти. В період від 20- до 25-добового віку в слизовій оболонці дванадцятипалої кишки лімфоїдні структури характеризуються переважним розвитком ДЛТ з появою поодиноких ЛВ3 (рис. 1).

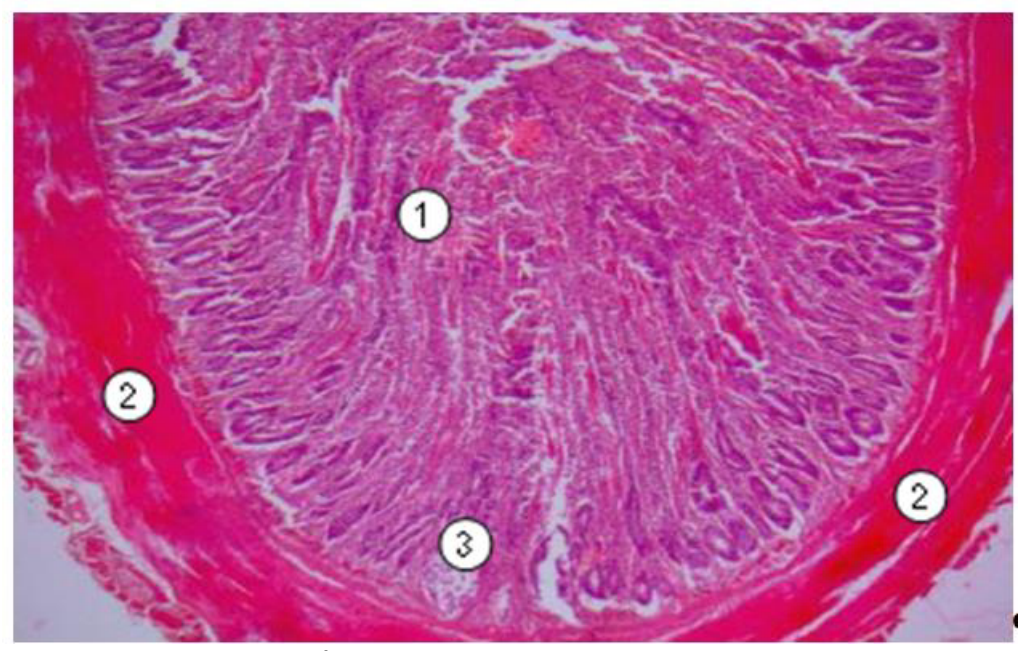

Рис. 1. Дванадцятипала кишка 25-добової мускусної качки: 1 - власна пластинка слизової оболонки, 2 - м'язова оболонка, 3 - лімфатичний вузлик. Заб. гематоксиліном і еозином, ×400, Leica CX100.

У слизовій оболонці порожньої і клубової кишки качок, починаючи з 30-добового віку, паралельно з дЛТ відмічається формування ретикулярної строми ЛВ3, що представлена густою сіткою звивистих волокон, які, з'єднуючись між собою, утворюють дрібні комірки. В подальшому формуються так звані «ретикулярні кошики» (рис. 2). Гермінативний центр ЛВ3 має більш розріджені ретикулярні волокна, між відростками яких розташовуються лімфоцити і макрофрагоцити. 

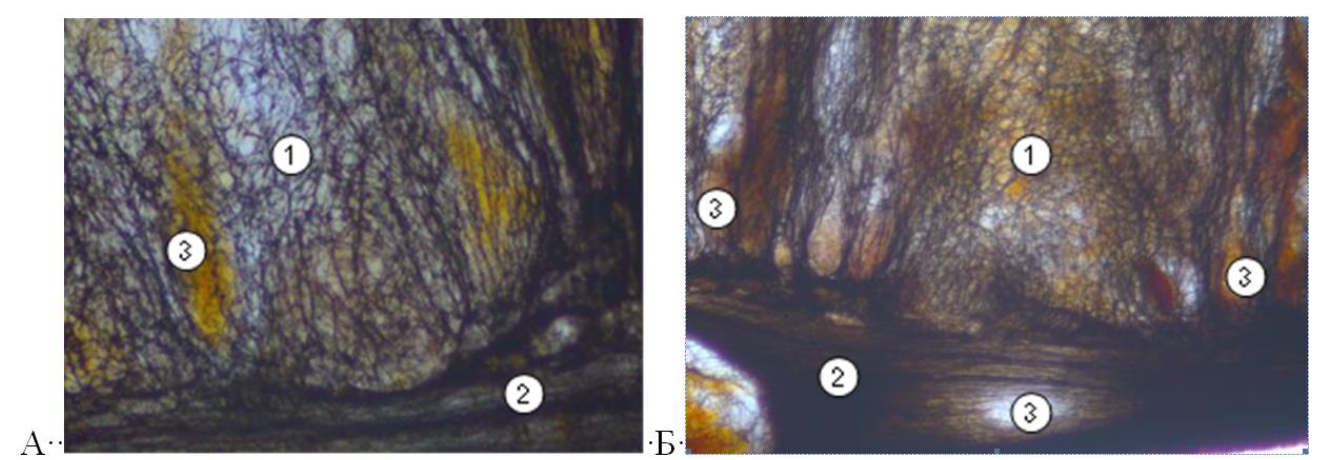

Рис. 2. Порожня кишка 25-добової (А) та 30-добової (Б) мускусної качки: 1 - власна пластинка слизової оболонки, 2 м'язова оболонка, 3 - лімфатичний вузлик. Імпрегнація азотнокислим сріблом за Футом, ×400, Leica CX100.

Архітектоніка ретикулярних волокон агрегованих ЛВ3 30-добових мускусних качок характеризується формуванням рівномірних сіток ретикулярних волокон. До 60-добового віку ретикулярні волокна стають більш щільними, розташову- ються без певної орієнтації. Поміж товстих волокон виявляються тонкі ретикулярні волокна. Переплітаючись між собою і товсті, і тонкі ретикулярні волокна утворюють густу сітку (рис. 3).
A

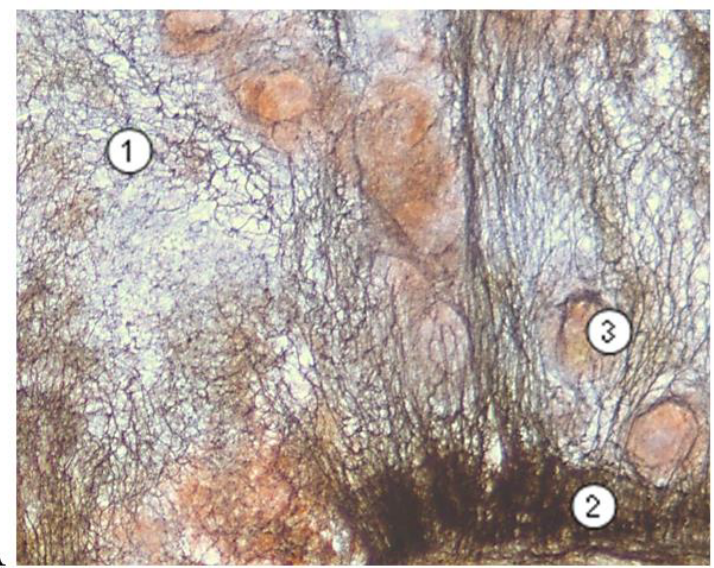

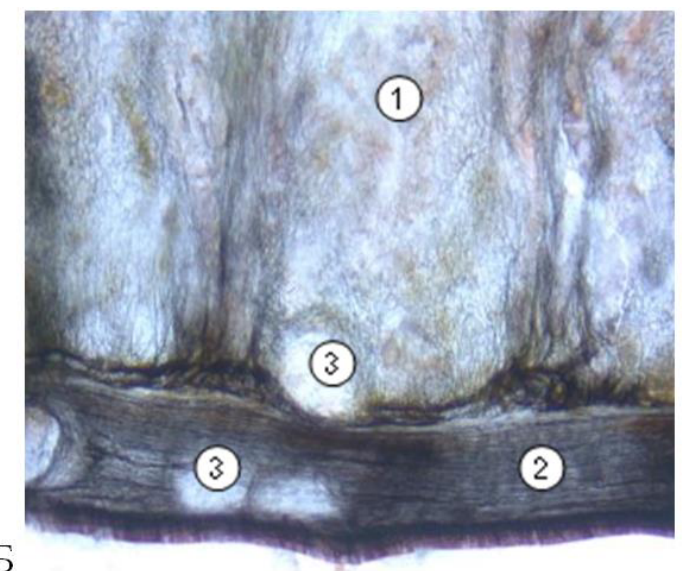

Б

Рис. 3. Порожня кишка 60-добової (А) та 90-добової (Б) мускусної качки: 1 - власна пластинка слизової оболонки, 2 м'язова оболонка, 3 - лімфатичний вузлик. Імпрегнація азотнокислим сріблом за Футом, ×400, Leica CX100.

Слід відмітити, що повний комплекс морфологічних ознак імунологічної реактивності в ЛВЗ порожньої та клубової кишок виявляється у 60-добової птиці. На тканинному рівні кишкову бляшку формують ЛВ3, що розміщуються у власній пластинці слизової оболонки, переважно, в ділянці основи кишкових ворсин. ЛВЗ локалізовані серед ДЛТ, яка заповнює проміжки між кишковими ворсинками та криптами, місцями

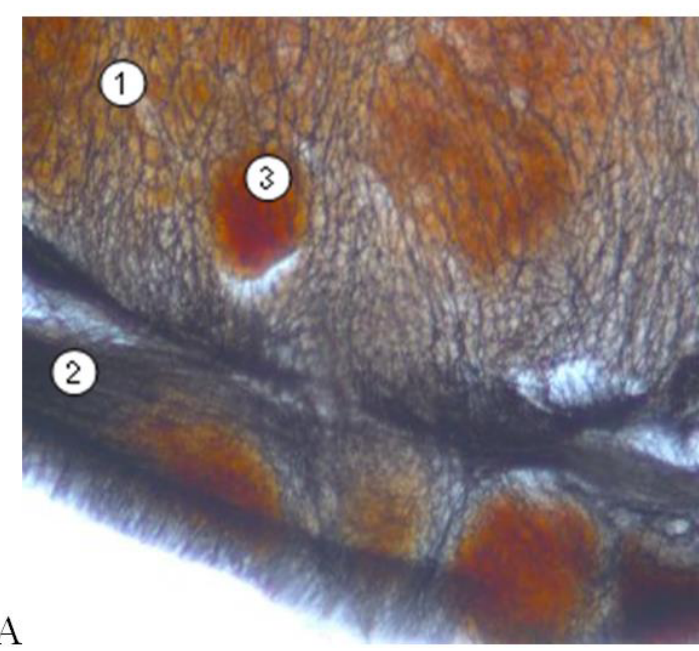

Б

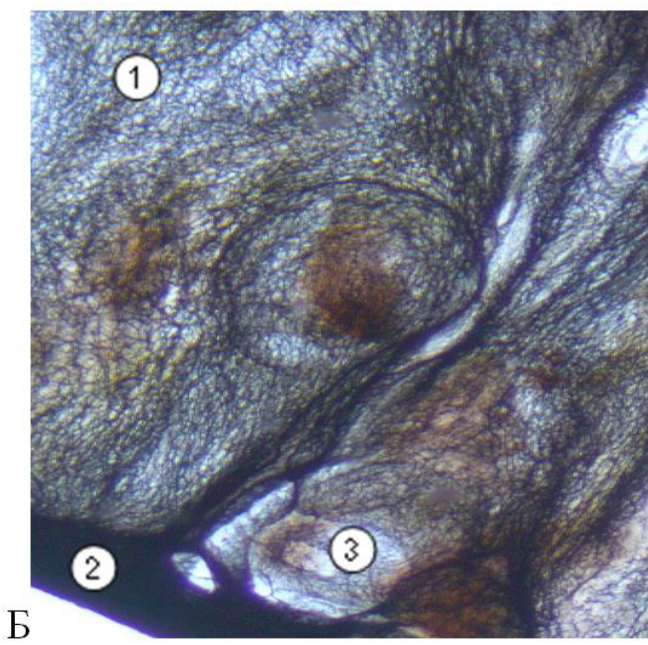

Рис. 4. Клубова кишка 60-добової (А) та 210-добової (Б) мускусної качки: 1 - власна пластинка слизової оболонки, 2 - м'язова оболонка, 3 - лімфатичний вузлик. Імпрегнація азотнокислим сріблом за Футом, ×600, Leica CX100. 
Ретикулярна основа вторинних ЛВЗ має великокоміркову структуру із слабо вираженими «ретикулярними кошиками» по периферії. Деякі ЛВ3 пронизують м'язову пластинку слизової оболонки та розміщуються в товщі м'язової оболонки групами по декілька штук, утворюючи скупчення, відмежовані один від одного м'язовими прошарками. Розмір ЛВ3 м'язової оболонки значно поступається тим, що розташовані у власній пластинці слизової оболонки.
Від 120- до 240-добового віку (настання статевої зрілості) в слизовій оболонці всіх відділів тонкої кишки завершується формування ЛВ3 як з центрами, так і без центрів розмноження. В порожній і клубовій кишках збільшується розмір та кількість агрегованих ЛВ3, в складі яких превалюють ЛВ3 з центрами розмноження (рис. 5).
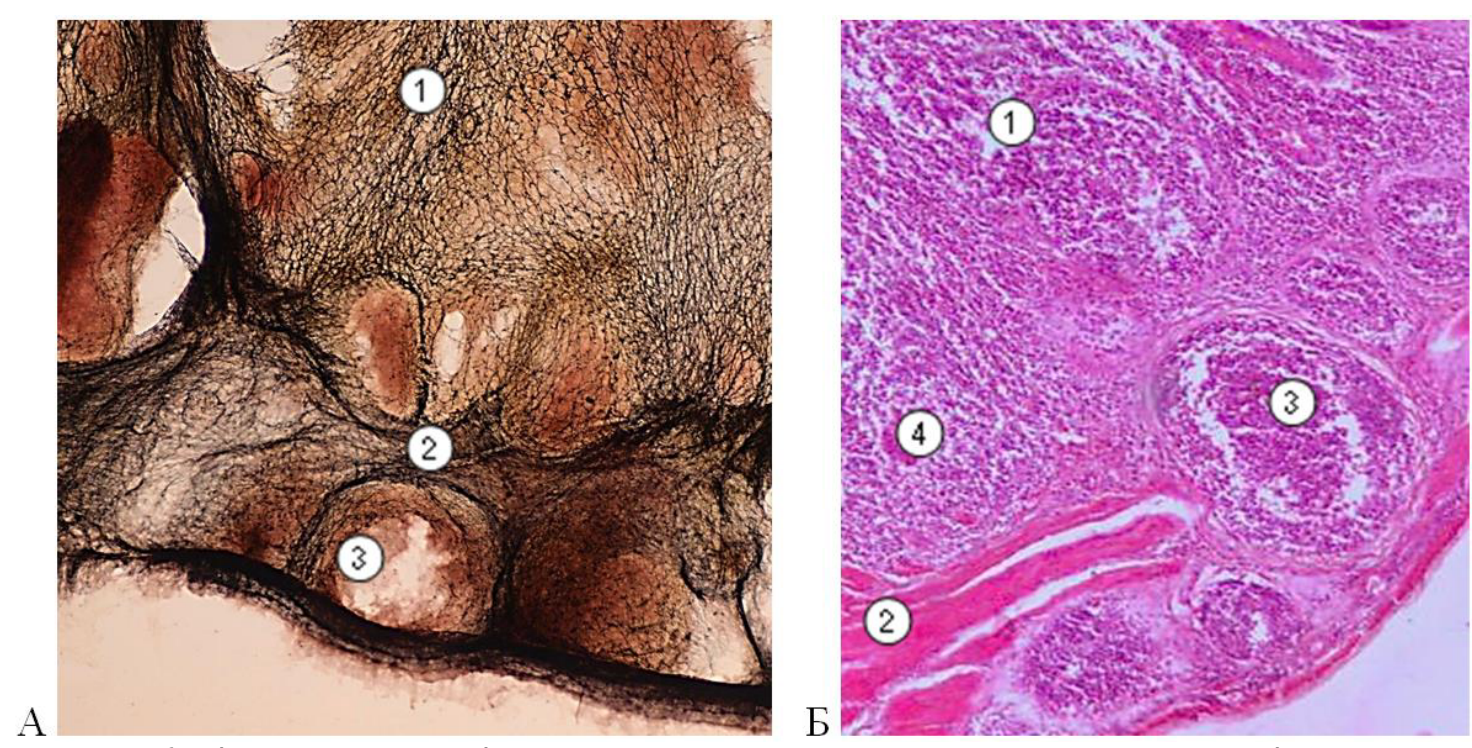

Рис. 5. Клубова кишки 240-добової мускусної качки: 1 - власна пластинка слизової оболонки, 2 - м'язова оболонка, 3 - лімфатичний вузлик, 4 - дифузна лімфоїдна тканина.

А - імпрегнація азотнокислим сріблом за Футом, $\times 400$

Б - заб. гематоксиліном і еозином, ×400, Leica CX100.

Обговорення та інтерпретація проведеного дослідження, порівняння 3 дослідженнями інших вчених. Сучасний етап досліджень травної системи визначний тим, що з'являється можливість вивчати процеси на клітинному рівні, а також взаємодію органів і тканин. Для нормального функціонування і виконання своїх фізіологічних функцій - органи травлення мають бути морфологічно сформовані. На особливу увагу заслуговує вивчення морфології і розвитку лімфоїдних структур органів травлення мускусних качок у віковому аспекті в нормі, в умовах наближених до природних, не використовуючи жодних препаратів для вакцинації птиці.

У вітчизняній і зарубіжній літературі по порівняльній анатомії хребетних і анатомії свійської птиці дані про особливості динаміки відділів кишечника птиці розрізнені і суперечливі. Всі дослідники і автори анатомії і фрізіології свійської птиці вказують, що в період постембріонального онтогенезу зростання органів ШКТ йде нерівномірно (Kotsiumbas I.Ya., Zhyla M.I., Piatnychko O.M., Shkodiak N.V., 2019) встановили, що у курчат найбільше інтенсивне зростання органів ШКТ випереджає збільшення маси тіла спостерігається в перші 15 діб після вилуплення, а за даними (Polyshchuk, SV., 1991) в період від 30 до 90-денного віку курей.

Основу імунних утворень кишечника складає лімфоїдна тканина, яка в своєму розвитку послідовно проходить 4 рівні структурної організації: ДЛТ $\rightarrow$ передвузлик $\rightarrow$ первинний ЛВ3 $\rightarrow$ вторинний ЛВ3. Першим етапом $€$ утворення лімфоїдних скупчень, щільність розташування яких по периферії менша, ніж в центрі і поки без чіткої межі між ними. Це так звана дифузна або передвузликова стадія. Другим етапом вважається поява щільних, округлої або овальної форми груп клітинних елементів, що формують ЛВ3, які прийнято розглядати як готовність лімфоїдної тканини до імунного захисту організму. Появу в ЛВ3 гермінативних або світлих центрів «Setory», або «реактивних центрів», що збільшуються в розмірах при антигенній дії на організм, прийнято вважати третім етапом становлення імуногенезу. Четвертим етапом $€$ зворотний їх розвиток - зникнення ЛВЗ при віковій інволюції. На нашу думку, структурно-функціональні зони ПБ тонкої кишки мускусних качок ідентичні відповідним структурам ссавців (Lohvinova et al., 2020). Лімфоїдна тканина представлена ретикулярними елементами, малими і середніми лімфоцитами, плазматичними клітинами, макрофагами. В зрілих ЛВ3 кишечника (Batuev., 1984) виділяє обідок з ретикулярних волокон, які утворюють своєрідну капсулу і надають їм форму. ЛВЗ органів травлення - це клітинні скупчення округлої або овальної фрорми, які складаються з петель ретикулярної тканини, утвореної ретикулярними клітинами, волокнами і клітинами лімфоїдного ряду (лімфоцитів різної величини і ступеня зрілості, плазмоцитів, макрофрагів) (Kajiwara et al., 2003).

Архітектоніка ретикулярних волокон не завжди однакова. В одних бляшках волокна розміщені по периферії вузликів, що формує волокнистий обідок сітчастої капсули. Цей обідок з ретикулярних волокон або повністю оточує вузлик, або переривається з боку вузлика, оберненого до епітеліального покриву кишки. В одній бляшці може зустрічатися обидва види вузликів - з ретикулярними обідками і без них. Ретикулярний обідок (Batuev., 1984) розглядає як капсулу деяких вузликів і вважає, що саме обідок надає властиву їм форму. ЛВЗ з ретикулярним обідком $€$ морфологічно більш зрілими. Формування ретикулярних обідків ЛВЗ у складі ПБ співпадає з морфофункціональною зрілістю даних органів.

У роботах (Kotsiumbas et al., 2019), (Mazurkevych \& 
Khomych., 2017) та (Kalinovskaya., 2005) підтверджується, що імунні утворення, які забезпечують специфічну імунологічну реактивність, активно фрормуються в перші тижні та місяці життя поступово, починаючи з лімфоїдних структур слизової оболонки органів травлення і закінчуючи лімфоїдними органами внутрішнього середовища організма.

Згідно даних (Batuev., 1984) в лімфоїдних бляшках, що локалізуються в дистальних відділах клубової кишки, лімфатичні вузлики розміщені в слизовій оболонці та в підслизовій основі, порушуючи цілісність м'язової пластинки слизової оболонки. Така ж картина спостерігається при їх розміщенні в декілька рядів або при наявності дуже великих вузликів. Ці дані співпадають з результатами наших досліджень, але не повністю. Відмінністю $€$ те, що автор наголошує на особливостях будови лише в дистальному відділі клубової кишки, а в дослідженої нами птиці, дані особливості будови ПБ присутні як в порожній, так і в клубовій кишках. В інших відділах порожньої і клубової кишок, як стверджує (Batuev., 1984) лімфоїдні вузлики залягають головним чином в товщі слизової оболонки і рідше в підслизовій основі. 3 цими даними співпадають дослідження (Mazurkevych \& Khomych., 2017) та (Kalinovskaya., 2005).

Висновки 3 проведеного дослідження і перспективи подальших розвідок у цьому напрямку. Диференціація лімфоїдних структур порожньої та клубової кишок має особливості та відбувається в певній послідовності. Перший етап (5-25 діб) характеризується переважним розвитком ДЛТ; другий (25-60 діб) - формуванням ЛВ3 без центрів та з центрами розмноження; третій (60-240 діб) - активним утворенням агрегованих ЛВ3, появою центрів розмноження і формуванням вторинних ЛВ3; четвертий (90-240 діб) - збільшенням розмірів ЛВ3 та локалізацією майже по всій товщі власної пластинки слизової оболонки, що призводить до місцевого руйнування кишкових залоз та утворення своєрідних «септ». У подальшому ЛВЗ пронизують м'язову пластинку слизової оболонки та розміщуються також у м'язовій оболонці групами, відмежованими м'язовими прошарками.

\section{References:}

1. Batuev K.M. (1984). Yzmenenye kletochnoho sostava ahrehyrovannыkh follykulov tonkoi kyshky beloi krisi pry kormlenyy preparatom DDT. Morfohenez lymfatycheskoi i krovenosnoi system v ykh tkanei v norme, pry patolohyy y v эksperymente [Changes in the cellular composition of the ahrehyrovannyh follicles of the small intestine of the white cress when fed the drug DDT. Morphogenesis of lymphatic and circulatory systems of tissues in norm, at pathology in experiment]. Perm, 23-25.

2. Birka E.V. (2019)/ Dynamyka morfoheneza lymfoydnoi tkany i ee topohrafyia v stenke lymfoydnoho dyvertykula husei.[ Dynamics of morphogenesis of lymphoid tissue and its topography in the wall of the lymphoid diverticulum of Geese] Uchenie zapysky uchrezhdenyia obrazovanyia «Vytebskaia hosudarstvennaia akademyia veterynarnoi medytsyni». 55(2). 7-10.

3. Havrylin P.M., Nikitina M.O. (2017). Mikroanatomichni osoblyvosti kyshechnyku ta imunnykh struktur, asotsiiovanykh z yoho slyzovoiu obolonkoiu, u kroliv miasnoho napriamu vykorystannia. [Microanatomical features of the intestine and immune structures associated with the mucous membrane in rabbits for direct use]. Theoretical and Applied Veterinary Medicine. 7, №11. 4246. doi.org/10.32819/2019.71008 (in Ukrainian).

4. Horalskyy, L. P., Khomych, V. T., \& Kononskyy, O. I. (2019). Osnovy histolohichnoyi tekhniky i morfofunktsionalni metody doslidzhen u normi ta pry patolohiyi [Fundamentals of histological techniques and morphological methods of investigation in normal and pathological conditions]. Zhytomyr, Polissya Publ (in Ukrainian).

5. Jung, C., Hugot, J.-P., \& Barreau, F. (2010). Peyer's patches: The immune sensors of the intestine. International Journal of Inflammation, 823710, 1-12.

6. Kalinovskaya, I.G. (2005). Growth and development of Peyer's plaque of the ileum of chickens in the postnatal period of ontogeny. News of Dnipropetrovsk State Agrarian University. 2. 229-232 (in Ukrainian).

7. Kotsiumbas I.Ya., Zhyla M.I., Piatnychko O.M., Shkodiak N.V. (2019). Morfofunktsionalni osoblyvosti imunnoi systemy ptytsi. Naukovo-tekhnichnyi biuleten Derzhavnoho naukovo-doslidnoho kontrolnoho instytutu veterynarnykh preparativ ta kormovykh dobavok i Instytutu biolohii tvaryn. 20(1). 255-262.

8. Kajiwara, E., Shigeta, A., Horiuchi, H., Matsuda, H., \& Furusawa, S. (2003). Development of Peyer's patch and cecal tonsil in gut-associated lymphoid tissues in the chicken embryo. Journal of Veterinary Medical Science. 65(5). 607-614.

9. Lohvinova V. V., Oliiar A. V., Lieshchova M. O. (2020). Formuvannia imunnykh struktur tonkoi kyshky muskusnykh kachok. [Formation of immune structures of a small intestine of musk ducks] Theoretical and Applied Veterinary Medicine. 8(1). 50-55. https://doi.org/10.32819/2020.81008

10. Mazurkevych T.A., Khomych V.T. (2017). Osoblyvosti lokalizatsii limfoidnoi tkanyny v imunnykh utvorenniakh stinky kyshechnyku, dyvertykuli mekkelia i slipokyshkovykh dyvertykulakh kachok [Features of localization of lymphoid tissue in the immune formation of the intestinal wall, diverticula of Meckellia and slipokyshkovyk diverticula of ducks]. Naukovyi visnyk Lvivskoho natsionalnoho universytetu veterynarnoi medytsyny ta biotekhnolohii imeni S.Z. Gzhytskoho. 19 (82). S. 30-35.

11. Mazurkevych T.A. (2020)/ Morfofunktsionalni osoblyvosti imunnykh utvoren kyshechnyka sviiskoi kachky (Anas platyrhynchos var. domestica) u postnatalnomu periodi ontohenezu [Morphofunctional features of immune formations of intestinal duckweed (Anas platyrhynchos var. Domestica) in the postnatal period of ontogeny] : avtoref. dys. d-ra vet. nauk : 16.00.02. Kyiv, 2020. 44.

12. Makhotina D.S., Kushch M.M., Miroshnikova O.S. (2020). Osoblyvosti mikroskopichnoi budovy slipykh kyshok kachok. [Features of microscopic structure of blind duck guts]. Veterynariia, tekhnolohiia tvarynnytstva ta pryrodokorystuvannia. [Veterinary medicine, technology of animal husbandry and nature management]. №6. 56-63.

13. Samoiliuk V.V., Havrylin P.M., Bilyi D.D., Kozii M.S., Maslikov S.M. (2019). Topohrafiia i mikrostrukturna orhanizatsiia limfoidnykh utvoriv, asotsiiovanykh zi slyzovoiu obolonkoiu kyshechnyka porosiat [Topography and microstructural organization of lymphoid formations associated with the mucous membrane of the intestinal piglets]. Theoretical and Applied Veterinary Medicine. 7(4). 189-197.

14. Tishkina N.M., Oliiar A.V. (2013). Tsytoarkhitektonika parenkhimy limfatychnykh vuzliv shlunkovo-kyshkovoho traktu 
porosiat u rannomu postnatalnomu periodi ontohenezu. [Cytoarchitectonics of parenchymal lymph nodes of the gastrointestinal tract of piglets in the early postnatal period of ontogeny]. Problemy zooinzhenerii ta vet. medytsyny: Zb. nauk. prats Kharkivsk. derzh. zoovet. akad. Kharkiv [Problems of zooengineering and vet. medytsyny], 27 (2). 40-43.

Vita Logvinova, PhD, Dnipro State Agrarian and Economic University, (Dnipro, Ukraine)

Alla Oliyar, PhD, Dnipro State Agrarian and Economic University, (Dnipro, Ukraine)

Histoarchitectonics of lymphoid formations of the mucosa of the small intestine of muscy ducks

Features of morphogenesis of intestinal lymphoid structures of poultry, especially in the period from birth to the onset of physiological maturity, when there is an intensive formation of the immune system, must be carefully considered in intensive poultry, which determines the widespread use of biological drugs with active antigenic action. From healthy unvaccinated ducks were selected duodenum and ileum, examined by general methods: macro-microanatomy and topography of lymphoid structures of the mucous membrane of the small intestine, performed by Hellman method, paraffin histological sections were stained Ehrlich hematoxylin and eosin, azure II-eosin and impregnated with silver by Foot. Age of experimental ducks: 1, 5, 10, 15, 20, 25, 30, 60, 90, 120, 150, 180, 210 and 240 days. It is established that morpho-functional differentiation and specialization of lymphoid formations of the small intestine has age and regional features, occurs in a certain sequence. In the mucous membrane of the duodenum and ileum of ducklings from 25 days of age in parallel with the diffuse lymphoid tissue is the formation of the reticular stroma of the lymph nodes. In the mature (reactive) nodule, the embryonic center and the peripheral part, the mantle, which consists mainly of small lymphocytes, is clearly distinguished. Characteristically, the number and size of nodules increases with age. The reticular network of lymph nodes, at the same time is thinned, to its partial thinning, and further and fragmentation.

Key words: diffuse lymphoid tissue, lymphatic nodules, aggregated lymphatic nodules, lymphoid cells, duodenal, caecal and jejunum, muscy ducks 